\title{
The word of the President!
}

\section{Philippe Gaulard}

Published online: 15 August 2012

(C) Springer-Verlag 2012

Paris, July 20, 2012

After the last very successful congresses of the European Association for Haematopathology (EAHP) in the wonderful cities of Uppsala (2010), Bordeaux (2008), and Vienna (2006), we are now welcomed by Dr. José Cabeçadas in another historical European city, Lisbon. Time is going fast and since the first formal meeting held in Geneva in 1988, this is already the XVI meeting of the EAHP, and I have been very honored to succeed very famous past presidents, the last one being our friend Philip Kluin. As in the past, the meeting is organized on behalf of the EAHP and the Society for Hematopathology (SH) and gives the opportunity to reinforce the link between both societies and colleagues from both sides of the Atlantic. After all, Lisbon is the westernmost large city in Europe, the European capital city closest to America!

The EXCO members together with Dr. José Cabeçadas, as the chairman of Local Organizing committee, have set up a fascinating and complete program that will allow us to examine the exciting topic of "peripheral T and NK-cell cell lymphomas" from every angle, i.e., immunology, genetics, clinical aspects, and histopathology. Before the EAHP lymphoma symposium, the EAHP educational session aims to cover the principles of the WHO classification of T and NKcell cell lymphomas and to give an overview on the practical approach to the diagnosis of T-cell lymphoma and the main entities. The Bone Marrow Symposium and workshop organized by the European Bone Marrow Workshop will cover the T-cell lymphoma/leukemia in the bone marrow and blood, as well as the neoplastic and reactive $\mathrm{T}$ cell

\section{P. Gaulard $(\bowtie)$}

Département de Pathologie, Hôpital Henri Mondor,

Université Paris Est (UPEC) and Inserm U955,

51 Av Ml de Lattre de Tassigny,

94010 Creteil Cedex, France

e-mail: philippe.gaulard@hmn.aphp.fr infiltration of the bone marrow. The EAHP lymphoma symposium will combine invited lectures by distinguished speakers and oral presentations which have been selected among a total number of abstracts received close to 150 as well as a session for poster discussions. The symposium will be followed by a slide workshop that has been organized in five sessions covering the spectrum of peripheral $\mathrm{T}$ and NKcell cell lymphomas and their mimics. Around 220 cases have been received and the selection has been hard among very interesting and often challenging cases! I have no doubt that, like in the past, this will result in unlived exchanges, novel ideas, and fruitful discussion with the participants and will take our knowledge on these lymphomas "a step forward!" Early risers will also have the possibility to join one of the early morning-meet-the professor sessions. These sessions are open to a limited number of active attendants to favor a close interaction between the professor and the participants.

Among the new releases of the congress, we are also pleased to announce that after 8 years of absence- the last thymus symposium was held in the EAHP meeting in Thessaloniki in 2004-a thymus mini-symposium organized by Prof. Alexander Marx will be held at this meeting. In addition, thanks to Dr. Han van Krieken, I am also very pleased that the abstracts could be printed in this special issue of the Journal of Hematopathology that also contains the workshop report of the previous meeting in Uppsala on "Early lesions in lymphoid neoplasia" and will be distributed to each participant. We hope you will appreciate this initiative.

Regarding the budget, the EXCO members and I did our best to keep the registration fee as low as possible, especially for the members of the EAHP-SH and for residents. In addition, in order to promote the educational and scientific development of hematopathology and facilitate the participation of hematopathologists, residents, and $\mathrm{PhD}$ students from developing countries to attend the XVIth Symposium 
and Workshop of EAHP in Lisbon, registration fee waivers and travel grants have been made available for those who have an abstract at the symposium or a case in the workshop accepted. We hope that this will make our active society even more attractive for pathologists and scientists interested in hematopathology from the five continents.

Above all, I hope that this meeting will represent for you a special period outside of work at your institution, a time of fruitful exchanges in a friendly atmosphere. Since 1988 where I participated for the first time to an EAHP congress in Geneva, I have never missed any of the EAHP meetings. I have learnt a lot, and these meetings have always been the opportunity to meet colleagues from different parts of the world sharing discussions on science and other matters, as well as to discover new cities or countries. I will certainly encourage you to discover or rediscover the charms of the historical city of Lisbon at the crossroads of several civilizations. You should not miss the Belem Tower and Jeronimos Monastery on the Tagus River and also the charms of the narrow streets in the old city center. Please remember that the Vasco de Gama expedition left from Lisbon to discover the sea route to India. For sure, thanks to your attendance and your active participation, the XVIth EAHP meeting in Lisbon will open the road to advances and discoveries in the field of T-cell lymphomas and hematopathology. Finally, I would like to take this opportunity to deeply thank the panel members for their great contribution to the preparation of the workshop, the EXCO members for their help in organizing the meeting, with my special gratitude to Dr. José Cabeçadas, and also to Leticia QuintanillaFend, Daphne de Jong, and Elias Campo who, as meeting secretary, secretary-treasurer, and president elect, respectively, spared no efforts to make this meeting successful.

On behalf of the EXCO members and of Dr. José Cabeçadas, I wish you a memorable meeting in Lisbon.

Philippe Gaulard

President of the EAHP 